\title{
EFFECT OF ESTROGEN-PROGESTIN HORMONAL REPLACEMENT THERAPY ON BLOOD COAGULATION AND FIBRINOLYSIS IN POSTMENOPAUSAL WOMEN
}

Claudio E Bonduki ${ }^{1}$, Dayse M Lourenço ${ }^{2}$, Eduardo L.A. da Motta ${ }^{1}$, José Maria Soares Jr${ }^{1}$, Mauro Abi Haidar ${ }^{1}$, Edmund C. Baracat ${ }^{1}$

Bonduki CE, Lourenço DM, Motta ELA, Soares Jr. JM, Haidar MA, Baracat EC. Effect of estrogen-progestin hormonal replacement therapy on blood coagulation and fibrinolysis in postmenopausal women. Clinics. 2007;62(5):553-60.

OBJECTIVE: To evaluate antithrombin III (AT), thrombin (Fragment $1+2[\mathrm{~F} 1+2]$ and thrombin-antithrombin [TAT]) generation markers, as well as other coagulation parameters, such as prothrombin time, partial activated thromboplastin time, thrombin time, fibrinogen, euglobulin lysis time, and platelet count, in postmenopausal women after hormonal therapy.

STUDY DESIGN: Forty-five patients who received either $0.625 \mathrm{mg} /$ day unopposed oral conjugated equine estrogen (CEE), $0.625 \mathrm{mg}$ /day oral CEE plus medroxyprogesterone acetate (MP), or $50 \mu \mathrm{g} /$ day transdermal 17beta-estradiol plus MP, were included. Tests were performed before (T0) and after 3 (T3), 6 (T6) and 12 (T12) months of treatment. AT was determined by an amidolytic method, whereas F1+2 and TAT complex were measured by ELISA.

RESULTS: There was a significant reduction in the AT level of patients who received oral CEE plus MP at T3. There was no AT reduction in patients taking either oral CEE alone or transdermal 17beta-estradiol plus MP. F1+2 increased in all patients, but it reached statistical significance only in patients receiving transdermal 17beta-estradiol MP at T3.

CONCLUSIONS: The CEE associated with MP treatment may reduce AT levels, whereas unopposed CEE or transdermal 17betaestradiol plus MP does not change AT. These changes might not be clinically relevant in the general population; however, hormonal replacement therapy may increase the risk of thrombosis in women with congenital or acquired thrombophilia.

KEY-WORDS: Antithrombin III. Postmenopausal hormonal therapy. Estrogen. Menopause. Thromboembolism. Thrombin generation.

\section{INTRODUCTION}

Traditionally, the blood coagulation scheme has been divided into extrinsic and intrinsic pathways, converging at the point where factor $\mathrm{X}$ is activated. The intrinsic pathway (partial activated thromboplastin time) may be initiated in vitro by the activation of factor XII, while the extrinsic pathway (prothrombin time) is activated by the tissue factor. However, such a division is mainly an artifact

${ }^{1}$ Federal University of São Paulo - Gynecology

${ }^{2}$ Federal University of São Paulo - Medic Clinic- Hematology

Email: jose.soares415@gmail.com

Received for publication on May 11, 2007

Accepted for publication on June 01, 2007 of in vitro testing, and in vivo, there are interconnections between the two pathways. For example, a tissue factor of the extrinsic pathway, factor VIIa complex, also activates factor IX in the intrinsic pathway. The coagulation cascade activation determines the increase in activation of thrombin. In turn, thrombin converts circulating soluble fibrinogen into insoluble fibrin, resulting in local fibrin deposition and induction of further platelet recruitment and aggregation to form a hemostatic plug. In addition to catalyzing the final steps of the coagulation cascade, thrombin also exerts a variety of effects on the local vasculature and inflammation. It even actively participates in limiting the extent of the hemostatic process. Once activated, the coagulation cascade must be restricted to the local site of vascular injury 
to prevent clotting of the entire vascular tree. Besides restricting factor activation to sites of exposed phospholipids, clotting is also regulated by three types of natural anticoagulants-proteins $\mathrm{C}$ and $\mathrm{S}$, tissue factor pathway inhibitor, and antithrombin III-that inhibit the activity of thrombin and other serine proteases. ${ }^{1}$

Besides inducing coagulation, activation of the clotting cascade also sets into motion a fibrinolytic cascade that limits the size of the final clot. This is primarily accomplished by the generation of plasmin, which breaks down fibrin and interferes with its polymerization. The resulting fibrin split products can also act as weak anticoagulants, and their elevated levels are helpful in diagnosing abnormal thrombotic states, such as deep venous thrombosis. There are several clot lysis tests available to assess the presence of increased fibrinolysis in the clinical situation. The euglobulin lysis test is actually a modified plasma clot lysis time, which detects increased plasminogen activation and subsequent fibrinolysis. ${ }^{2}$ It is important to emphasize that a disturbance in normal hemostasis may result in thrombosis. ${ }^{2}$

Hormone therapy (HT) in postmenopausal women minimizes the risk of osteoporosis and promotes relief of many climacteric symptoms. ${ }^{3}$ Several case-control studies demonstrated an increased incidence of venous thrombosis among HT users. ${ }^{4-8}$ A meta-analysis performed by Meade ${ }^{9}$ showed a higher incidence of venous thrombosis with HT, usually at the beginning of treatment. HT-triggered blood clotting modifications that contribute to thrombosis are particularly important to identify in women with other thrombotic risk factors, such as hereditary or acquired thrombophilia. $^{10}$

Two large randomized prospective studies have refuted observational studies that found cardioprotective effects from hormone therapy. The Heart and Estrogen/Progestin Replacement Study (HERS) was a randomized trial designed to evaluate HT effects on the secondary prevention of coronary heart disease. The results indicated that HT enhanced coronary events within the first year of followup after acute myocardial infarction (AMI) among patients treated with a combination of conjugated estrogens/ medroxyprogesterone acetate at fixed doses, and a mean age of 66.7 years. ${ }^{11}$ In addition, the Women's Health Initiative (WHI) was interrupted early because of a higher incidence of cardiovascular events in women using HT compared to the placebo group. ${ }^{12}$ Recently, the results of the therapeutic arm of the WHI, evaluating unopposed conjugated equine estrogens (CEE) versus placebo among 10,739 hysterectomized postmenopausal women, were published. There was an increased risk of stroke ( $\mathrm{rr}=1.39,95 \% \mathrm{CI}$ : 110-177), a decreased risk in hip fracture, and no effect on the incidence of cardiovascular disease, as well as a po- tential reduction in the incidence of breast cancer. Overall, the risk-benefit index was neutral. ${ }^{13}$

Results of the main randomized studies, HERS 2 and WHI, indicate increased risk of venous thromboembolism (VTE) with the use of HT. ${ }^{12,14}$ It is important to highlight that these studies were criticized in at least two respects: patient selection, which included women on average 10 years older than the age at which HT is usually recommended (WHI), and the range of HR regimens used in both studies, in terms of drugs, administration, and doses. Also, the estrogen replacement and atherosclerosis (ERA) trial randomly assigned more than 300 women with proven coronary artery disease to estrogen, a combined estrogenprogestin, or placebo. VTE, reported as an adverse effect, was not significantly different among the groups. ${ }^{15}$ Rosano et al (2003) suggested that hormone therapy had beneficial cardiovascular effects in early postmenopausal women, while it may have had detrimental effects on coagulative balance and vascular inflammation. ${ }^{16}$

The administration route of HT appears to affect the fibrinolytic activity and the coagulation markers. Also, the oral route is associated with changes in the levels of coagulation and fibrinolysis markers, especially during the early period of use. ${ }^{17-19}$ Studies using the transdermal route, however, did not confirm these findings. ${ }^{20-21}$ Moreover, Scarabin et al. (2003), ${ }^{22}$ in a multicenter case-control study, evaluated 155 postmenopausal women hospitalized because of venous thromboembolism (VTE). They demonstrated an increased risk for VTE with oral, but not transdermal, therapy. ${ }^{23}$ Therefore, we decided to investigate the effect of oral versus transdermal estrogen-progestin treatment on AT-III levels in postmenopausal women, and compare them to unopposed conjugated equine estrogen therapy. There is a strong association between reduced levels of antithrombin III and the development of thrombosis. ${ }^{24}$ This is thought to be related to the anti-Xa activity. ${ }^{25} \mathrm{We}$ also evaluated the thrombin $(\mathrm{F} 1+2$ and TAT) generation markers, as well as other coagulation parameters, such as prothrombin time, partial activated thromboplastin time, thrombin time, fibrinogen, euglobulin lysis time, and platelet count, in postmenopausal women after hormonal therapy, all important parameters for analyzing the coagulation processes.

\section{MATERIALS AND METHODS}

A total of 45 postmenopausal women selected from the Department of Gynecology of the Federal University of São Paulo - Escola Paulista de Medicina were included in our study (last natural menstruation at least 12 months prior to entering the study, and $\mathrm{FSH}>40 \mathrm{mIU} / \mathrm{mL}$, aged from 40 to 62 years, median $=54.6$ years $)$. In order to be in- 
cluded in this study, women could not have had uterine bleeding or have used hormone therapy in the 180 days preceding admission to the study.

The following groups were deemed ineligible based on the exclusion criteria: women with a body mass index e" 35 ; women who were taking vitamin supplements (vitamins B6, B12 or folic acid), herbal substances, or phytoestrogens; those who practiced physical exercise (with the exception of light walks less than three times a week); those who had endometrial thickness $>5 \mathrm{~mm}$ according to ultrasonography carried out within the previous six months; those who had any abnormality detected by recent mammography or cervicovaginal oncological colpocytology (carried out in the previous 12 months); and those who presented a personal history of cardiovascular disease or venous or arterial thromboembolism. Women presenting dyslipidemia, diabetes mellitus, or acute or chronic hepatopathies were also excluded, as were those using cholesterol-reducing medication, androgens, raloxifene, tamoxifen, barbiturates, hydantoin, carbamazepine, phenylbutazone, meprobamate, or rifampicin, and those with hormone-dependent cancer. We also excluded patients using medication that could interfere with blood clotting. All subjects voluntarily agreed to participate in the study, which was approved by the institution's Ethics Committee in Research, and all patients gave their written informed consent to participate in the study. Precocious menopause was not included.

Patients were divided into three groups: A) oral conjugated equine estrogens (CEE), $0.625 \mathrm{mg} /$ day $(\mathrm{n}=15)$; B) oral CEE, $0.625 \mathrm{mg} / \mathrm{day}$, plus medroxyprogesterone (MP) ( $\mathrm{n}=15) ; \mathrm{C})$ transdermal 17beta-estradiol, $50 \mu \mathrm{g} /$ day, plus MP (group $\mathrm{C}, \mathrm{N}=15)$. MP ( $5 \mathrm{mg} /$ day) was given from the first to the fourteenth day of each month. The patients in the unopposed estrogen treatment were all hysterectomized. Baseline blood values were obtained $\left(\mathrm{T}_{0}\right)$, as were blood values after three $\left(\mathrm{T}_{3}\right)$, six $\left(\mathrm{T}_{6}\right)$, and $12\left(\mathrm{~T}_{12}\right)$ months of hormone treatment. Samples were also collected between the $12^{\text {th }}$ and $14^{\text {th }}$ day of each month of treatment (during the MP treatment phase).

Plasma antithrombin III (AT-III) activity was measured by a functional method (amidolytic procedure) using a chromogenic substrate, in the presence of polybrene, as the substrate for residual thrombin. p-Nitralinine (p-NA) released from the substrate H-D-Phe-Pip-Arg-p-NA was measured photometrically at $405 \mathrm{~nm}$ using the end-point procedure. The amount of thrombin inhibited by the antithrombin III-heparin complex is proportional to the amount of antithrombin III present.

Prothrombin time (PT), partial activated thromboplastin time (APTT), and thrombin time (TT) were measured in fresh citrated plasma by standard methods, and the results were expressed as the ratio of test sample/normal plasma pool. Fibrinogen, as well as euglobulin lysis time (ELT), was determined according to the method of Clauss, using previously frozen plasma. ELISA assays were used to measure fragment $1+2(\mathrm{~F} 1+2$, Organon Teknika) and thrombin-antithrombin III complex (TAT, Diagnostica Stago).

Four patients left this study for either personal reasons ( $\mathrm{n}=1$ from group $\mathrm{A}$ ), abnormal bleeding ( $\mathrm{n}=1$ from group $\mathrm{B})$, nausea and headache ( $\mathrm{n}=1$ from group $\mathrm{B}$ ), or breast pain ( $n=1$ from group $\mathrm{C}$ ).

\section{Statistical methods}

An alpha error $(\mathrm{P})$ of 0.05 was used. All values in the figures and text are expressed as mean \pm standard deviation. All statistical tests were performed using GraphPad Prism 3.00 for Windows (GraphPad Software, San Diego, CA). The characteristic data of the groups was analyzed by one-way repeated measures analysis of variance and post-hoc Bonferroni tests. The number of patients per group for a power calculation of $75 \%$ was 15 per group.

\section{RESULTS}

Figure 1 shows the values of antithrombin III levels during this study. AT-III levels in patients of group B (oral CEE plus MP) presented a reduction at $\mathrm{T}_{3}(92 \pm 7 \%, \mathrm{p}<0.05)$ compared to baseline (pretreatment, $100 \pm 5), \mathrm{T}_{6}(104 \pm$ 5), and $\mathrm{T}_{12}(100 \pm 6)$. There were no AT-III level changes in patients of group A (unopposed CEE) and group C (transdermal 17beta-estradiol plus MP).

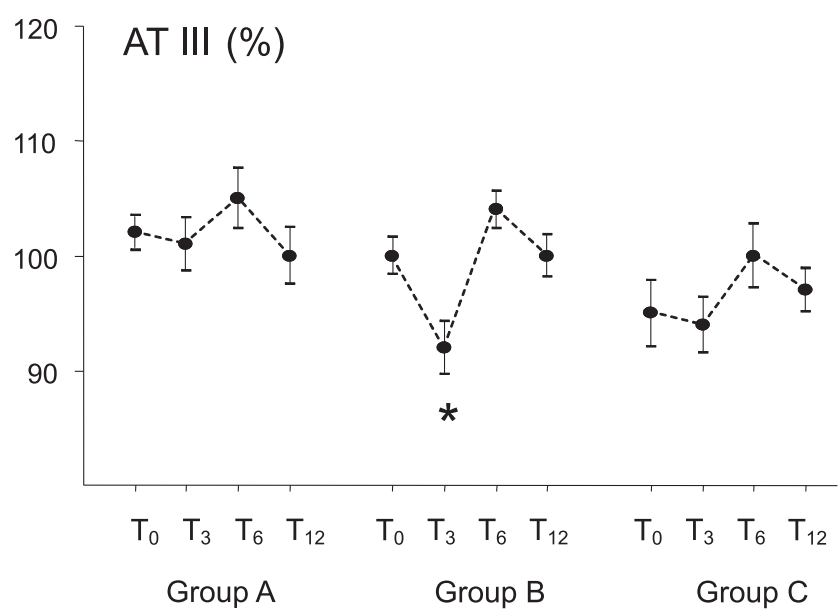

Figure 1 - Antithrombin III (AT-III) levels (mean \pm standard error) during one year of hormone therapy in patients receiveing oral CEE (group A), oral CEE plus MP (group B), or transdermal 17 $\beta$-estradiol plus MP (group C). ${ }^{*}=\mathrm{p}<0.05$, compared to initial values. 
Table 1 summarizes the values of the coagulation parameters analyzed in this study. F1+2 increased in all patients after three months of treatment $(0.20 \pm 0.25,0.26 \pm$ 0.15 , and $0.27 \pm 0.14$, for groups $\mathrm{A}, \mathrm{B}$ and $\mathrm{C}$, respectively), but it reached statistical significance only in group $\mathrm{C}(0.10$ \pm 0.19 and $0.27 \pm 0.14$, for baseline and $\mathrm{T} 3$, respectively, $\mathrm{p}<0.05)$. TAT levels decreased at $\mathrm{T}_{3}$ in all groups $(13.7 \pm$ 3.2, $13.1 \pm 4.6$, and $15.1 \pm 0.14$, for groups $\mathrm{A}, \mathrm{B}$ and $\mathrm{C}$, respectively), but this reduction was only significant in group B $(16.1 \pm 3.9$ and $13.1 \pm 4.6$, baseline and T3, respectively, $\mathrm{p}<0.05)$. Fibrinogen levels were significantly higher at $\mathrm{T}_{12}$ in groups $\mathrm{B}(3.9 \pm 0.8)$ and $\mathrm{C}(4.3 \pm 2.0)$ compared to their respective baselines $(3.0 \pm 0.5$ and $2.8 \pm 0.5$, groups $\mathrm{B}$ and $\mathrm{C}$, respectively, $\mathrm{p}<0.05$ ).

Table 1 - Results (mean \pm standard deviation) of AT, F1+2, TAT, and fibrinogen determinations during one year of hormone replacement therapy $\left(\mathrm{T}_{0}\right.$ through $\left.\mathrm{T}_{12}\right)$ in patients receiveing oral CEE (group A), oral CEE plus MP (group B), or transdermal $17 \beta$-estradiol plus MP (group C).

\begin{tabular}{lcccc}
\hline & $\mathrm{T}_{0}$ & $\mathrm{~T}_{3}$ & $\mathrm{~T}_{6}$ & $\mathrm{~T}_{12}$ \\
\hline & \multicolumn{5}{c}{ Group A } \\
AT-III (\%) & $102 \pm 5$ & $101 \pm 7$ & $105 \pm 8$ & $100 \pm 8$ \\
F 1+2 (nmol/l) & $0.12 \pm 0.1$ & $0.20 \pm 0.25$ & $0.20 \pm 0.12$ & $0.35 \pm 0.3$ \\
TAT (ng/ml) & $16.2 \pm 4.3$ & $13.7 \pm 3.2$ & $14.8 \pm 4.3$ & $15.5 \pm 3.9$ \\
Fibrinogen (g/l) & $3.3 \pm 0.7$ & $3.1 \pm 0.5$ & $3.2 \pm 0.6$ & $3.9 \pm 1.5$ \\
& \multicolumn{5}{c}{ Group B } \\
AT-III (\%) & $100 \pm 5$ & $92 \pm 7 *$ & $104 \pm 5$ & $100 \pm 6$ \\
F 1+2 (nmol/l) & $0.14 \pm 0.14$ & $0.26 \pm 0.15$ & $0.18 \pm 0.12$ & $0.24 \pm 0.16$ \\
TAT (ng/ml) & $16.1 \pm 3.9$ & $13.1 \pm 4.6 *$ & $15.6 \pm 2.7$ & $15.9 \pm 3.1$ \\
Fibrinogen (g/l) & $3.0 \pm 0.5$ & $2.7 \pm 0.5$ & $2.9 \pm 0.7$ & $3.9 \pm 0.8 *$ \\
& \multicolumn{5}{c}{ Group C } \\
AT-III (\%) & $95 \pm 9$ & $94 \pm 7$ & $100 \pm 9$ & $97 \pm 6$ \\
F 1+2 (nmol/l) & $0.10 \pm 0.19$ & $0.27 \pm 0.14 *$ & $0.15 \pm 0.26$ & $0.11 \pm 0.16$ \\
TAT (ng/ml) & $18.1 \pm 8.2$ & $15.1 \pm 4.0$ & $16.5 \pm 3.5$ & $15.8 \pm 4,1$ \\
Fibrinogen (g/l) & $2.8 \pm 0.5$ & $2.9 \pm 0.4$ & $2.8 \pm 0.6$ & $4.3 \pm 2.0 *$ \\
\hline
\end{tabular}

$* \mathrm{p}<0.05$, compared to initial values. The normality rates for each test: ATIII (antithrombin III) -70 to $120 \%$; F $1+2$ (fragment $1+2$ ) $<1.1 \mathrm{nmol}$ " $\mathrm{L}$; TAT (thrombin-antithrombin III complex) - 10 to $41 \mathrm{ng} / \mathrm{mL}$; fibrinogen 2 to $4 \mathrm{~g} / \mathrm{L}$.

Table 2 shows the values of PT, APTT, TT, platelet count, and ELT during this study. PT was shortened in all patients from $\mathrm{T}_{3}$ through $\mathrm{T}_{12}$ compared to baseline in each group $(\mathrm{p}<0.05)$. APTT, TT, platelet count, and ELT were not modified during treatment in any group.

\section{DISCUSSION}

The hypercoagulability state is a condition that may induce the thrombosis phenomenon. In our study, the markers of this state were identified in patients who received estrogen associated with progestagens. Furthermore, the group that received oral estrogen plus medroxiprogesterone
Table 2 - Results (mean \pm standard deviation) of PT, APTT, TT, platelet count, and euglobulin lysis time during one year of hormone therapy in patients receiveing oral CEE (group A), oral CEE plus MP (group B), or transdermal $17 \beta$ estradiol plus MP (group C).

\begin{tabular}{lcccc}
\hline & $\mathrm{T}_{0}$ & $\mathrm{~T}_{3}$ & $\mathrm{~T}_{6}$ & $\mathrm{~T}_{12}$ \\
\hline & \multicolumn{5}{c}{ Group A } \\
PT (ratio) & $1.14 \pm 0.09$ & $0.97 \pm 0.04 *$ & $0.97 \pm 0.04 *$ & $1.01 \pm 0.04 *$ \\
APTT (ratio) & $0.92 \pm 0.2$ & $0.91 \pm 0.1$ & $1.03 \pm 0.1$ & $1.01 \pm 0.1$ \\
TT (ratio) & $1.08 \pm 0.1$ & $1.08 \pm 0.1$ & $1.09 \pm 0.1$ & $1.07 \pm 0.1$ \\
Platelets ${ }^{3} 10^{3} / ? 1$ & $193 \pm 49$ & $196 \pm 47$ & $215 \pm 105$ & $221 \pm 67$ \\
ELT (hours) & $5.6 \pm 0.5$ & $5.0 \pm 0.7$ & $5.3 \pm 0.7$ & $5.6 \pm 0.8$ \\
& \multicolumn{5}{c}{ Group B } \\
PT (ratio) & $1.21 \pm 0.10$ & $0.98 \pm 0.10 *$ & $0.96 \pm 0.06 *$ & $1.00 \pm 0.04 *$ \\
APTT (ratio) & $1.05 \pm 0.1$ & $1.02 \pm 0.1$ & $1.11 \pm 0.2$ & $1.05 \pm 0.1$ \\
TT (ratio) & $1.10 \pm 0.1$ & $1.06 \pm 0.1$ & $1.07 \pm 0.1$ & $1.13 \pm 0.1$ \\
Platelets $\times 10^{3} / \mu \mathrm{L}$ & $173 \pm 34$ & $183 \pm 29$ & $187 \pm 36$ & $203 \pm 50$ \\
ELT (hours) & $5.7 \pm 0.5$ & $5.2 \pm 0.8$ & $5.4 \pm 0.7$ & $5.8 \pm 0.5$ \\
& \multicolumn{5}{c}{ Group C } \\
PT (ratio) & $1.06 \pm 0.12$ & $0.96 \pm 0.07 *$ & $1.02 \pm 0.06 *$ & $1.01 \pm 0.06 *$ \\
APTT (ratio) & $1.06 \pm 0.2$ & $1.17 \pm 0.1$ & $1.14 \pm 0.1$ & $1.07 \pm 0.1$ \\
TT (ratio) & $1.08 \pm 0.1$ & $1.06 \pm 0.1$ & $1.06 \pm 0.1$ & $1.09 \pm 0.1$ \\
Platelets $\times 10^{3} / \mu \mathrm{L}$ & $185 \pm 32$ & $245 \pm 26$ & $255 \pm 26$ & $196 \pm 59$ \\
ELT (hours) & $5.6 \pm 0.7$ & $5.4 \pm 0.9$ & $5.4 \pm 0.9$ & $5.5 \pm 0.8$ \\
\hline
\end{tabular}

$* \mathrm{p}<0.05$, compared to initial values. The normality rates for each test: PT (prothrombin time) 0.85 to 1.20 ; APTT (partial activated thromboplastin time -0.80 to 1.25 ; TT $<1.20$; platelets 150.000 to $400.000 / \mathrm{m} 3$; ELT (euglobulin lysis time) $>5$ hours.

showed a decrease in antithrombin III, which is a risk factor for thrombosis. Therefore, our results suggest that this (these) association(s) lead to a procoagulant state.

In a previous study, we observed AT-III reduction in patients receiving oral CEE plus MP, and no AT-III change in patients taking transdermal 17beta-estradiol and MP. ${ }^{26}$ These results are confirmed by the current study; the ATIII levels decreased only in women taking oral CEE plus MP, and they were not changed by a transdermal 17betaestradiol plus MP regimen. It is interesting to note that this effect on AT-III disappeared when oral CEE was used without MP in the present study.

Oral CEE caused AT-III reduction in some studies on the effect of short- and long-term hormone therapy. ${ }^{27-30}$ Some authors observed AT-III reduction with ethinyl estradiol ${ }^{31-33}$ and with estradiol valerate. ${ }^{32,33}$ On the other hand, AT-III reduction during HT with oral CEE was not observed by others, but this may be due to methodology. For example, the Gilabert ${ }^{34}$ conducted a transversal study where AT-III was measured only once, and Elzelsberger et al. ${ }^{35}$ measured AT-III levels by an immunological method. In our prospective study, patients were observed for one year and differences were detected in relation to initial values. The study design or the method used for AT-III determination can account for these discrepancies.

As in our previous study ${ }^{26}$ we did not observe AT re- 
duction in patients taking transdermal 17 beta-estradiol plus MP. This data suggests that oral estrogen decreases AT-III levels, an effect that is not observed with transdermal administration, avoiding the first-pass effects of intestinal and hepatic metabolism. Sporrong ${ }^{36}$ observed an AT-III level decrease in patients taking transdermal 17beta-estradiol, but only in those who used larger prostagen doses, suggesting that progestagens, rather than estrogens alone, may be responsible for these changes in hemostasis.

F1+2 and TAT complex are sensitive markers for activation of blood coagulation. ${ }^{37-39}$ Monitoring these markers can identify a hypercoagulable state associated with a statistically significant reduction of AT-III levels, despite remaining within the normal range (higher than 70\%). F1+2 levels increased after three months of treatment in all the groups, compared to the initial values. They reached statistical significance only in patients receiving transdermal 17beta-estradiol plus MP at $\mathrm{T}_{3}$; that is, in patients with no AT-III reduction. This is in contrast with the findings of Kroon $^{27}$ and Caine, ${ }^{29}$ who observed high F1+2 levels in women receiving oral CEE, though this phenomenon was not seen in those receiving transdermal 17beta-estradiol. As we observed for AT-III and F1+2 levels, they were always within the normal range, suggesting that the elevation is not clinically relevant.

There was a TAT complex reduction in all of the groups at $\mathrm{T}_{3}$, but it was significant only in the women taking oral CEE associated with MP (group B), the same patients who showed a significant AT reduction. This is an intriguing finding, which was also observed by Kroon ${ }^{27}$ in patients receiving oral CEE. In spite of having high F1+2 levels, suggesting a hypercoagulable state, patients had a lower production of the TAT complex. Perhaps the reduction of ATIII levels could have contributed to this fact. Other authors did not observe an increase of $\mathrm{F} 1+2$ or TAT in users of oral CEE or transdermal 17beta-estradiol. ${ }^{40-41}$

The shortening of PT observed in all groups could be related to the increase in factor VII. Meade ${ }^{42}$ observed a PT reduction, and Lindberg ${ }^{33}$ found higher factor VII lev- els in women on HRT. APTT and TT did not change in this or other studies. ${ }^{35,36,42}$

Fibrinogen levels increased at $T_{12}$ in patients receiving MP associated with either oral CEE or transdermal 17betaestradiol. In fact, estrogens seem to reduce fibrinogen levels, a fact which is reverted by progestagen, as observed here and in other studies. ${ }^{41,43-45}$

As in our previous study, ${ }^{26}$ we did not detect changes in fibrinolytic activity, as evaluated by the euglobulin lysis time. Reduced PAI-1 levels and higher t-PA levels after HRT have been reported, which can increase the fibrinolytic potential in these patients. ${ }^{46-48}$

These results confirm that oral CEE plus MP can reduce AT-III levels, as we observed previously, whereas unopposed CEE or transdermal 17beta-estradiol associated with MP did not change AT-III levels. There is no evidence of activation of blood coagulation, since the AT-III level was not reduced below normal range, and the F1+2 elevation was only modest. We believe that these changes are not clinically relevant when the general population is considered. However, more studies are necessary to evaluate the impact of postmenopausal hormone therapy in women with other risk factors for thrombosis, such as congenital or acquired thrombophilia.

Also, the disturbances in the endothelial function play an important role in the pathophysiology of cardiovascular disease, and several lines of evidence suggest that interventions in the endothelial function could modify the progression of cardiovascular risk factors. Therefore, further studies are needed to test the impact of hormone therapy on the endothelial function, using inflammatory markers such as decreased expression of adhesion molecules (e.g., ICAM-1, VICAM-1 and E-selectin or C-reactive protein $\left.{ }^{49-53}\right)$, fibrinolytic/thrombogenic markers ${ }^{54,55}$ and functional methods (e.g., ultrasonography of the brachial artery and plasma nitrite/nitrate level measurements) to determine the real risk of hormone therapy on postmenopausal cardiovascular disease.

\section{RESUMO}

Bonduki CE, Lourenço DM, Motta ELA, Soares Jr. JM, Haidar MA, Baracat EC. Efeitos da terapia de reposição hormonal estroprogestativa sobre o sistema de coagulação e de fibrinólise em mulheres na pós-menopausa.Clinics. 2007;62(5):553-60.

OBJETIVO: Avaliar os marcadores antitrombina III (AT), fragmento $1+2$ da trombina $(\mathrm{F} 1+2)$ e complexo trombina- antitrombina (TAT), bem como outros parâmetros da coagulação, como tempo de pró-trombina, tempo parcial de tromboplastina ativado, tempo de trombina, fibrinogênio e tempo de lise da euglobulina em mulheres na pós-menopausa após terapia hormonal.

DESENHO DO ESTUDO: Foram incluídas 45 voluntárias que receberam estrogênios conjugados eqüinos (ECE) $0,625 \mathrm{mg} / \mathrm{dia}$, isoladamente ou associado ao acetato de 
medroxiprogesterona (AMP) ou usaram o 17beta-estradiol (50 $\mu \mathrm{g} /$ dia) transdérmico com AMP. Os exames foram realizados antes do tratamento (T0) e após três (T3), seis (T6) e doze (T12) meses após o início do tratamento. AT foi avaliada pelo método amidolítico, enquanto que o F1+2 e o complexo TAT por ELISA.

RESULTADOS: Houve redução significante nos níveis de AT em pacientes que receberam ECE associado ao AMP no T3. Não houve redução na AT em mulheres que usaram ECE isoladamente ou aquelas com 17beta-estradiol transdérmico e AMP. O F1+2 aumentou em todos os grupos, mas apenas o grupo com 17 beta-estradiol transdérmico e AMP apresentou diferença significante durante o T3. CONCLUSÕES: A associação de ECE e AMP pode reduzir os níveis de AT, enquanto ECE isoladamente ou 17betaestradiol transdérmico com AMP não modificam-o acentuadamente. Essas alterações poderiam ser mais relevantes clinicamente na análise populacional. Todavia, a terapia de reposição hormonal aumentaria o risco de trombose em mulheres com trombofilia prévia congênita ou adquirida.

UNITERMOS: Antitrombina III. Terapia hormonal da pósmenopausa. Estrogênio. Menopausa. Tromboembolismo. Gerador de trombina.

\section{REFERENCES}

1. Mitchell RN. Hemodynamic Disorders, Thromboembolic Disease, and Shock. In: Kumar V, Abbas AK, Fausto N, editors. Robbins and Cotran pathologic basis of disease. $7^{\text {Th }}$ ed. Philadelphia: Saunders, 2005, p. 4251.

2. Kaizu K, Abe M. Euglobulin lysis time (ELT).Nippon Rinsho. 2004;62(Suppl 12):584-5.

3. van de Weijer PH, Mattsson LA, Ylikorkala O. Benefits and risks of long-term low-dose oral continuous combined hormone therapy. Maturitas. 2007;56:231-48.

4. Canonico M, Oger E, Plu-Bureau G, Conard J, Meyer G, Levesque H, Trillot N, Barrellier MT, Wahl D, Emmerich J, Scarabin PY; Estrogen and Thromboembolism Risk (ESTHER) Study Group. Hormone therapy and venous thromboembolism among postmenopausal women: impact of the route of estrogen administration and progestogens: the ESTHER study. Circulation. 2007;115:840-5.

5. Daly E, Vessey MP, Hawkins MM, Carson JL, Gough P, Marsh S. Risk of venous thromboembolism in users of hormone replacement therapy. Lancet 1996;348:977-80.

6. Cushman M, Kuller LH, Prentice R, Rodabough RJ, Psaty BM, Stafford RS, Sidney S, Rosendaal FR; Women's Health Initiative Investigators. Estrogen plus progestin and risk of venous thrombosis.JAMA. 2004;292:1573-80.

7. Hemelaar M, Rosing J, Kenemans P, Thomassen MC, Braat DD, van der Mooren MJ. Less effect of intranasal than oral hormone therapy on factors associated with venous thrombosis risk in healthy postmenopausal women.Arterioscler Thromb Vasc Biol. 2006;26:16606.

8. Whitehead M, Godfree V. Venous thrombo-embolism and hormone replacement therapy. Baillieres Clin Obstet Gynaecol 1997;11:587-99.

9. Meade TW. Hormone replacement therapy and haemostatic function. Thromb Haem 1997;78:765-9.

10. Greer IA. Practical strategies for hormone replacement therapy and risk of venous thromboembolism. Br J Obstet Gynaecol 1998;105:376-9.
11. Hulley S, Grady D, Bush T, Fulberg C, Herrington D, Riggs B, et al. For the heart and estrogen/ progestin replacement study (HERS) research group. Randomized trial of estrogen plus progestin for secondary prevention of coronary heart disease in postmenopausal women. JAMA. 1998;280:605-13.

12. Writing Group for the Women's Health Initiative Investigators; Risks and benefits of estrogen plus progestina in healthy postmenopausal women. JAMA 2002;288:321-33.

13. The women's health initiative steering committee. Effects of conjugated equine estrogen in postmenopausal women with hysterectomy. JAMA 2004;291:1701-1712.

14. Grady D, Herrington D, Brittner V, Blumenthal R, Davidson M, Hlatky $\mathrm{M}$, et al. For the HERS Research Group. Cardiovascular disease outcomes during 6.8 years of hormone theraphy: Heart and Estrogen/ progestin Replacement Study follow-up (HERS II). JAMA. 2002;288:49-57.

15. Herrington DM, Resboussin DM, Brosnihan KB, Sharp PC, Shumaker SA, Snyder TE, et al. Effects of estrogen replacement on the progression of coronary artery atherosclerosis. N Engl J Med 2000;343:522-529.

16. Rosano GM, Vitale C, Silvestri A, Fini M. Hormone replacement therapy and cardioprotection: the end of the tale? Ann N Y Acad Sci. 2003;997:351-7.

17. Teede HJ, McGrath B P, Smolich JJ, Malan E, Kotsopoulou M, Liang YL, et al. Postmenopausal Hormone replacement teraphy increases coagulation activity and fibrinolysis. Arterioscler Thromb Vasc Biol 2000;20:1404-16.

18. Brown NJ, Abbas A, Byrne D, Schoenhard JA, Vaughan DE. Comparative Effects of Estrogen and Angiotensin-Converting Enzyme Inhibition on Plasminogen Activator Inhibitor-1 in Healthy Postmenopausal Women. Circulation. 2002;105:304-9.

19. Gottsater A, Rendell M, Hulthen UL. Hormone replacement theraphy in healthy postmenopausal women: a randomized, placebo-controlled study of effects on coagulation and fibrinolitic factors. J Intern Med. 2001;249:237-46. 
20. Perera M, Sattar N, Petrie JR, Hillier C, Small M, Connell JM, et al. The effects of transdermal estradiol in combination with oral norethisterone on lipoproteins, coagulation, and endothelial markers in postmenopausal women with type 2 diabetes: a randomized, placebo-controlled study. J Clin Endocrinol Metab. 2001;86:1140-3

21. Rabbani LE, Seminário NA, Sciacca RR. Oral conjugated equine estrogen increases plasma von Willebrand factor in postmenopausal women. JACC. 2002;40(11):1991-11.

22. Scarabin PY, Oger E, Plu-Bureau G. Differential association of oral and transdermal oestrogenreplacementtherapy with venous thromboembolism risk. Lancet 2003:428-32.

23. Wender MCO, Vitola D, Spritzer PM. Percutaneous 17beta estradiol replacement therapy in hypertensive post-menopausal women. Brazilian Journal of Medical and Biological Research. 1997;30:1047-53.

24. Akhtar N, Deleu D, Kamran S. Haematologic disorders and cerebral venous thrombosis. J Pak Med Assoc. 2006;56:498-501.

25. Petitou M, van Boeckel CA. A synthetic antithrombin III binding pentasaccharide is now a drug! What comes next? Angew Chem Int Ed Engl. 2004;43:3118-33.

26. Bonduki CE, Lourenço DM, Baracat EC, Haidar MA, Noguti MAE, Mota ELA, Lima GR. Effect of estrogen-progestin hormonal replacement therapy on plasma antithrombin III of postmenopausal women. Acta Obstet Gynecol Scand 1998; 77;330-3.

27. Kroon UB, Silfverstolpe G, Tengborn L. The effects of transdermal estradiol and oral conjugated estrogens on haemostasis variables. Thromb Haemost 1994;71:420-3.

28. Dias AR Jr, Melo RN, Gebara OC, D'Amico EA, Nussbacher A, Halbe HW, Pinotti JA. Effects of conjugated equine estrogens or raloxifene on lipid profile, coagulation and fibrinolysis factors in postmenopausal women. Climacteric. 2005;8:63-70

29. Caine YG, Bauer KA, Barzegar S, ten Cate H, Sacks FM, Walsh BW, Schiff I, Rosenberg RD. Coagulation activation following estrogen administration to postmenopausal women. Thromb Haemost 1992;68:392-5.

30. Kessler CM, Szymanski LM, Shamsipour Z, Muesing RA, Miller VT, LaRosa JC. Estrogen replacement therapy and coagulation: relationship to lipid and lipoprotein changes. Obstet Gynecol. 1997;89:326-31.

31. Aldrighi JM, De Campos LS, Eluf Gebara OC, Petta CA, Bahamondes L. Effect of a combined oral contraceptive containing 20 microg ethinyl estradiol and 75 microg gestodene on hemostatic parameters. Gynecol Endocrinol. 2006;22:1-4.

32. Gordon EM, Williams SR, Frenchek B, Mazur CA, Speroff L. Dosedependent effects of postmenopausal estrogen and progestin on antithrombin III and factor XII. J Lab Clin Med 1988;111:52-6.

33. Lindberg UB, Crona N, Stigendal L, Teger-Nilsson AC, Silfverstolpe G. A comparison between effects of estradiol valerate and low dose ethinyl estradiol on haemostasis parameters. Thromb Haemost 1989;61:65-9.

34. Gilabert J, Estelles A, Cano A, Espana F, Barrachin AR, Grancha S, Aznar J, Tortajada M. The effect of estrogen replacement therapy with or without progestogen on the fibrinolytic system and coagulation inhibitors in postmenopausal status. Am J Obstet Gynecol 1995;173:1849-54.
35. Enzelsberger H, Heytmanek G, Kurz C, Metka M. Hormone replacement therapy and its influence on AT-III activity in climacteric women. Klin Wochenschr 1991;69:232.

36. Sporrong T, Mattsson LA, Samsioe G, Stigendal L, Hellgren M. Haemostatic changes during continuous oestradiol-progestogen treatment of postmenopausal women. Br J Obstet Gynaecol 1990;97:939-44.

37. Mannucci PM, Tripodi A. Mechanisms, markers and management of hypercoagulable states. Haemostasis 1996;26(suppl 4):1-8.

38. Stegnar M, Cuderman TV, Bozic M. Evaluation of pre-analytical, demographic, behavioural and metabolic variables on fibrinolysis and haemostasis activation markers utilised to assess hypercoagulability. Clin Chem Lab Med. 2007;45:40-6.

39. Nekludov M, Antovic J, Bredbacka S, Blomback M. Coagulation abnormalities associated with severe isolated traumatic brain injury: cerebral arterio-venous differences in coagulation and inflammatory markers. J Neurotrauma. 2007;24:174-80.

40. Saleh AA, Dorey LG, Dombrowski MP. Thrombosis and hormone replacement therapy in postmenopausal women. Am J Obstet Gynecol 1993;169:1554-1557.

41. Brosnan JF, Sheppard BL, Norris LA. Haemostatic activation in postmenopausal women taking low-dose hormone therapy: Less effect with transdermal administration? Thromb Haemost. 2007;97:558-565

42. Meade TW, Berra A. Hormone replacement therapy and cardiovascular disease. Br Med Bull 1992; 48:276-308

43. Meilahn EN, Cauley JA, Tracy RP, Macy EO, Gutai JP, Kuller LH. Association of sex hormones and adiposity with plasma levels of fibrinogen and PAI-1 in postmenopausal women. Am J Epidemiol 1996; 143:159-66.

44. Nabulsi AA, Folsom AR, White A, Patsch W, Heiss G, Wu KK, Szklo M. Association of hormone-replacement therapy with various cardiovascular risk factors in postmenopausal women. The Atherosclerosis Risk in Communities Study Investigators. N Engl J Med 1993;328:1069-75.

45. Fait T, Vrablik M, Cibula D, Masata J, Hill M, Trnkova B. Oral but not transdermal estrogen replacement therapy reduced level of tissue factor pathway inhibitor: cross-over designed study. Neuro Endocrinol Lett. 2006; $27: 665-8$

46. van Wersch JW, Ubachs JM, van den Ende A, van Enk A. The effect of two regimens of hormone replacement therapy on the haemostatic profile in postmenopausal women. Eur J Clin Chem Clin Biochem $1994 ; 32: 449-53$

47. Gebara OC, Mittleman MA, Sutherland P, Lipinska I, Matheney T, Xu P, Welty PW, Levy D, Muller JE. Association between increased estrogen status and increased fibrinolytic potencial in the Framingham Offspring Study. Circulation 1995;9:1952-1958.

48. Shahar E, Folsom AR, Saloma W, Stinson VL, Mcgovern PG, Shimakawa T, Chambless LE, Wu KK. Relation of hormone replacement therapy to measures of plasma fibrinolytic activity. Atherosclerosis Risk in Communities (ARIC) Study Investigators. Circulation 1996;93:1970-5

49. Koh KK, Jin DK, Yang SH, Lee SK, Hwang HY, Kang MH, Kim W, Kim DS, Choi IS, Shin EK. Vascular effects of synthetic or natural progestagen combined with conjugated equine estrogen in healthy postmenopausal women. Circulation. 2001;103:1961-6. 
50. Hu P, Greendale GA, Palla SC, Reboussin BA, Henrrington DM, BarretConnor E, et al. The effects of hormone therapy on the markers of inflammation and endothelial function and plasma matrix metalloproteinase-9 level in postmenopausal women: The postmenopausal estrogen progestin intervention (PEPI) trial. Atherosclerosis. 2006;185:347-52.

51. Sumino H, Ichikava S, Kasama S, Takahashi T, Kumakura H, Takayama Y, et al. Different effects of oral conjugated estrogen and transdermal estradiol on arterial stiffness and vascular inflammatory markers in postmenopausal women. Atherosclerosis 2006; In Press.

52. Wakatsuki A, Ikenoue N, Shinohara K. Effect of Lower Dosage of Oral Conjugated Equine Estrogen on Inflammatory Markers and Endothelial Function in Healthy Postmenopausal Women. Arterioscler Thromb Vasc Biol, 2004;24:571-576.
53. Wakatsuki A, Okatani Y, Ikenove N, Fukaya T. Effect of Medroxyprogesterone Acetate on Vascular Inflammatory Markers in Postmenopausal Women Receiving Estrogen. Circulation 2002;105:1436

54. Duschek Ejj, Stehouwer CDA, Valk-DE Roo, GW. Raloxifene, conjugated oestrogen and endothelial function in postmenopausal women. J Intern Med. 2003;254:85-94

55. Lima SMR, Aldrighi JM, Consolin-Colombo FM, Mansur A, Rubira MC, Krieger EM, et al. Acute administration of 17b-estradiol improves endothelium-dependent vasodilation in postmenopausal women. Maturitas. 2005;50:266-74. 